\title{
Reliability of the Transport System in an Area Affected by the Mining Underground Activity
}

\section{Leopold HUDEČEK ${ }^{1)}$, Miloslav $\check{R} E Z A \check{C}^{2)}$, Denisa CIHLÁŘOVÁ(3), Otto ROHÁČ $\check{C}^{4)}$}

\footnotetext{
${ }^{1)}$ Ing. Ph.D.; Faculty of Civil Engineering, VŠB - Technical University of Ostrava, Czech Republic; email: leopold.hudecek@vsb.cz

2) doc. Ing. Ph.D.; Faculty of Civil Engineering, VŠB - Technical University of Ostrava, Czech Republic; email: miloslav.rezac@vsb.cz

3) Ing., Ph.D.; Faculty of Civil Engineering, VŠB - Technical University of Ostrava, Czech Republic; email: denisa.cihlarova@vsb.cz

4) Ing., MBA; Green Gas DPB, a.s.; email: otto.rohac@dpb.cz
}

http://doi.org/10.29227/IM-2020-01-09

Submission date: 13-11-2019 | Review date: 28-02-2020

\begin{abstract}
The paper deals with the negative effects of mining on the transport network in the Moravian-Silesian area, especially is focused on problems reflected in construction layers of transport-related structures (railways, roads, area storage and handling areas). With the extraction downturn, the sources and objectives of transport have changed including the characteristics of transport flows of all traffic roads and connections. Various measures for all transport modes situated in Moravian-Silesian region are identified and introduced in the both districts. Also new relevant directions of transport development are described considering efficiency, effectiveness. And also these measures are taken for to needs minimization negative impact on the health and quality of our environment while ensuring the transport services in the region.

The dynamic development of the Ostrava agglomeration is thus inseparably connected with black coal mining, metallurgy and railway development. The position of extraction companies was set by the position of the deposit, which resulted in the establishment of a polycentric system of settlement in the agglomeration. Further development of the coal railways at the end of the 19th century was related to the extraction capacities in the region of Karviná. The greatest industrial and development boom was experienced at the beginning of the 20th century where there were massive changes in the condition of the entire Ostrava basin. After 1989, with reduction in the mining work, primary „brownfields" started appearing in OKD, being industrial premises of the mines as well as secondary ",brownfields", which were disused railway siding stations and connecting railway sidings. High-performance, sufficiently efficient and comfort system of transport infrastructure appears to be a key factor for future development this area.

The development of mining in the past years was subject to a functional transport system, with prevailing requirements for the transportation of large volumes of extracted material, structural elements and people working in this industry. With the extraction downturn, the sources and objectives of transport have changed including the characteristics of transport flows of all traffic roads and connections. Thus, in this area it is necessary to identify the consequences of mining, reclaim the landscape, reconstruct civil structures and ensure safe and reliable transport through transport-engineering measures which may ensure the required transport standard and minimise its adverse environmental impacts.
\end{abstract}

Keywords: undermined area, terrain transformation, civil structure rectification, non-rigid civil structures, brownfields, line construction

\section{Development of the area and transport system}

Mining is usually associated with environmental impacts, in particular air pollution according to the sources of dust [1], [11], [12], [13]. The Moravian-Silesian Region, one of 13 regions, is located in the north and east of the Czech Republic. The protected black coal deposit is located here - the Upper Silesian Coal Basin. There are two types of undermined areas here: district of Ostrava where the mines have been closed down and the mining phenomena are considered terminated and Karviná, where coal is still mined and the impacts of mining are still present.

Industrial production has influenced the character of Moravia and Silesia since the turn of the 19th century when the country started being industrialised. Factories following the developed manufacture production depended largely on sources of fuel and this dependence was even increased by sparse and poor quality road network, which made the transport of raw materials over longer distances difficult.

The dynamic development of the Ostrava agglomeration is thus inseparably connected with black coal mining, metallurgy and railway development. The position of extraction com- panies was set by the position of the deposit, which resulted in the establishment of a polycentric system of settlement in the agglomeration. Further development of the coal railways at the end of the 19th century was related to the extraction capacities in the region of Karviná. The greatest industrial and development boom was experienced at the beginning of the 20th century where there were massive changes in the condition of the entire Ostrava basin. This trend continued, although it was strongly affected by WWI, until the 1930s. The railway used exclusively for the purposes of the coal mines was a part of the mining company Severní dráha Ferdinandova and was nationalised along with the company, which became the property of Ostravsko-karvinské kamenouhelné doly (OKD). Later, in 1952, the company OKD-Doprava was incorporated and it gradually took over the coal railways from Ostravsko-karvinské doly and České dráhy. This process was completed in 1980. At the peak of the extraction operations in $\mathrm{OKD}$, the railway siding network totalled ca. 400 $\mathrm{km}$ of railway sidings. After 1989, with reduction in the mining work, primary „brownfields“ started appearing in OKD, being industrial premises of the mines as well as secondary 


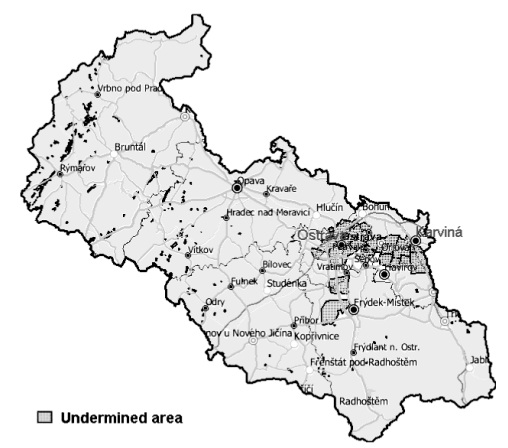

Fig. 1. Undermined area in Moravian-Silesian Region [2]

Rys. 1. Nieokreślony obszar w regionie morawsko-śląskim [2]

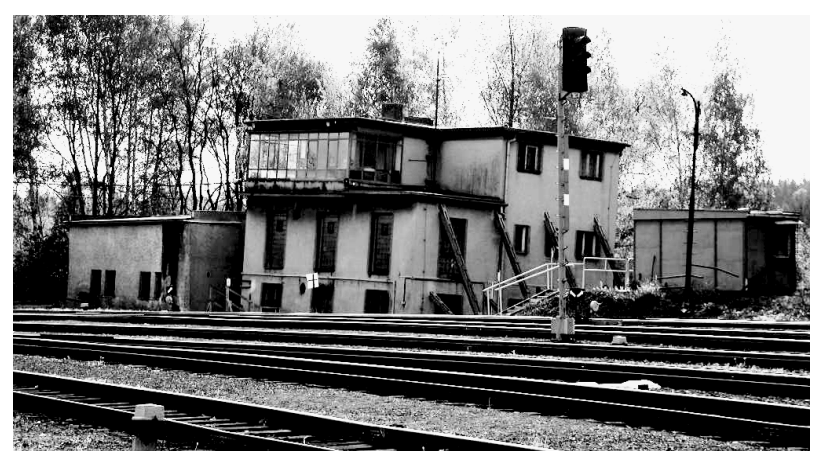

Fig. 2. Defects of transport-related civil structures: building of signal box - drop Rys. 2. Uszkodzenia konstrukcji cywilnych związane z transportem: budowa skrzynki sygnalizacyjnej
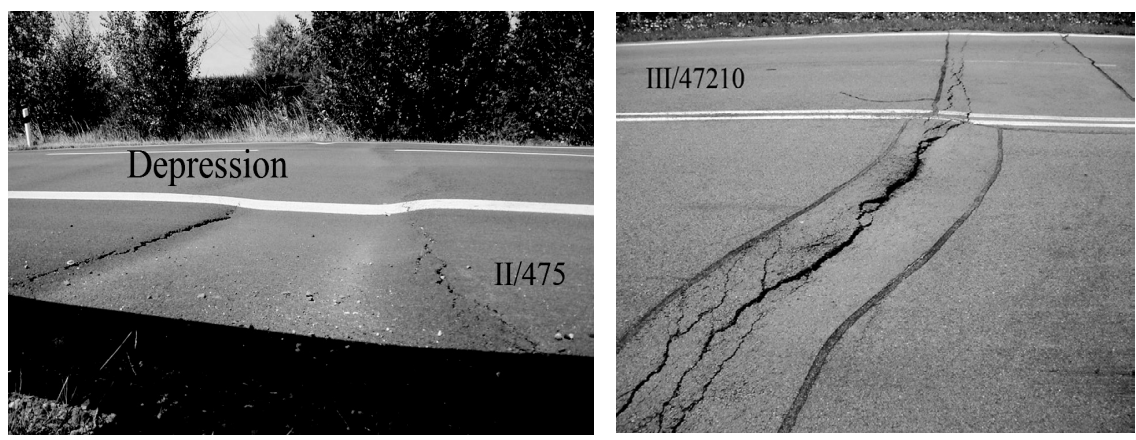

Fig. 3. Road defects

Rys. 3. Uszkodzenia dróg

„brownfields“,which were disused railway siding stations and connecting railway sidings. Currently, the length of these rails is $309 \mathrm{~km}$. Further development of the agglomeration with a size of $248.1 \mathrm{~km}^{2}$ with ca. 527 thousand inhabitants is affected by several larger settlements with a population of $50-100$ thousands people and the city of Ostrava with 311,000 people. High-performance, sufficiently efficient and comfort system of transport infrastructure appears to be a key factor for future development [6].

With the extraction downturn, the sources and objectives of transport have changed including the characteristics of transport flows of all traffic roads and connections. Thus, in this area it is necessary to identify the consequences of mining, reclaim the landscape, reconstruct civil structures and ensure safe and reliable transport [7].

The impacts of undermining can be behind a number of problems in various types of civil structures, however, trans- port structures are rather specific due to their line character [8], [9], [14]. This specificity is mainly due to the fact that line structures enter all parts of the subsidence basin and therefore they are negatively impacted by the subsidence and inclination as well as by horizontal shifts in longitudinal and cross directions. The impacts of mining operations are reflected in the line transport structures themselves but also in civil structures that are not directly related to the transport system (see Fig 2), but which are endangered by methane seeps. Besides the aforesaid negative impacts of undermining, there are risks to the reliability which are closely connected to changes in groundwater table, formation of flooded depressions, whose localisation may change in time depending on the operation.

\section{Roads}

A regards extensive road areas it is practically unconceivable to design the carriageway or base courses in a way 


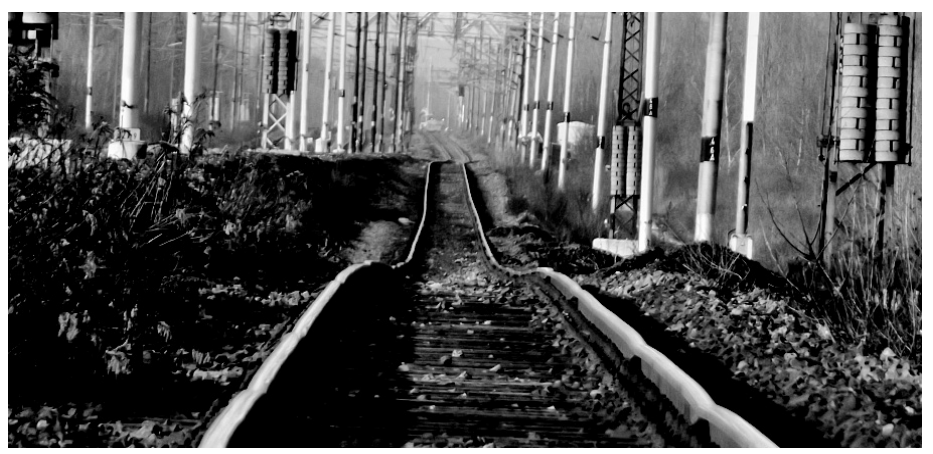

Fig. 4. Defects in rail alignment

Rys. 4. Uszkodzenia torów

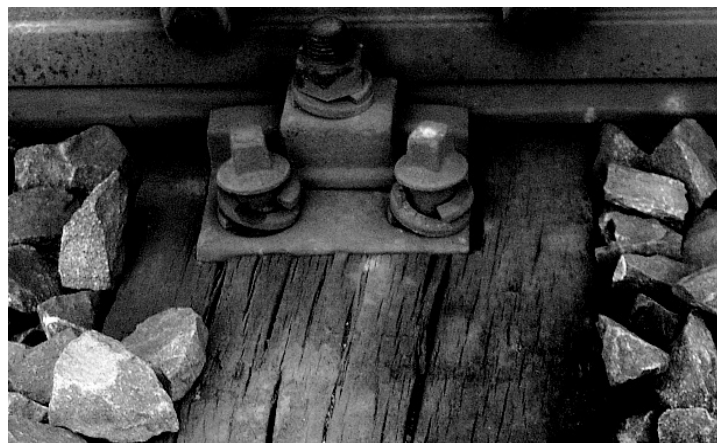

Fig. 5. Increased sleeper wear as a result of frequent handling during the rail geometrical position repair Rys. 5. Zwiększone zużycie podkładu kolejowego w wyniku częstych zmian położenia geometrycznego szyny
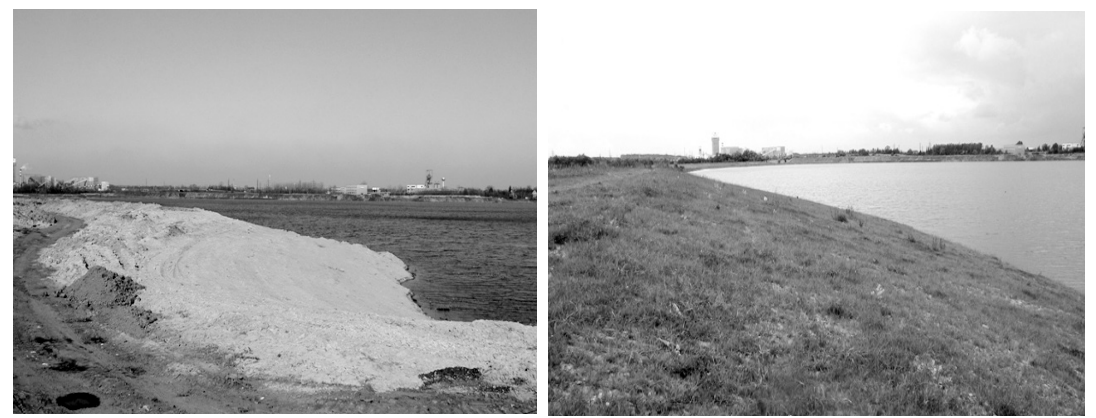

Fig. 6. Reclamation of the Darkov area, 1st stage $(2004,2006)$

Rys. 6. Rekultywacja obszaru Darkova, I etap $(2004,2006)$

resisting curvature or transformation (prolongation and compression) of the terrain. However, the required road and base course plasticity entails expected changes in the design parameters of the road. Besides changes in the design parameters, there is a number of minor defects occurring, in particular tensile cracks or pressure waves and uplifts (see Fig. 3) which also strongly deteriorates the road use conditions [10].

The carriageway and base course structures are very sensitive to the effects of terrain transformation. Therefore, for undermined areas it is always plastic and easily repairable structures that are designed [5]. It is forbidden to construct rigid cement-concrete roads of a permanent nature. The effects of relative horizontal terrain transformations create tensions in the road plain, embankments, base courses and the road. The rigid layers behave in a very adverse manner. They crack by the action of tensile stress from positive terrain prolongation $+\varepsilon$, as their high rigidity is combined with disproportionately low tensile strength, the action of negative terrain compression $-\varepsilon$ creates terrain waves, kerbs and flush kerbs get jammed and if dilatation joints are firmly filled, the contact points rise by up $0.5 \mathrm{~m}$. For these reasons we propose principally non-rigid road structures which get better adapted to the subsoil deformation, geometrical changes of the surface are more smooth and endanger road traffic to a leader extent. Road defects are demonstrated by a finer and more even network of cracks which are repaired through standard maintenance procedures (coatings, fine carpets) [16].

The requirements for road designs in undermined areas are closely related to the requirement for the rectified performance of safety systems and other road equipment. Any design or fastening is allowed ensuring its easily renewable functions [14]. 
Tab. 1. Composition of transport flow (\%) on the road network in Ostrava [2], [3], [4]

Tab. 1. Struktura przepływu transportu (\%) w sieci drogowej w Ostrawie [2], [3], [4]

\begin{tabular}{|l|c|c|c|}
\hline Name & year 2003 & year 2005 & year 2010 \\
\hline Trucks & 6,4 & 15,0 & 17,2 \\
\hline Buses (incl. public transport) & 4 & 2,2 & 1,9 \\
\hline
\end{tabular}

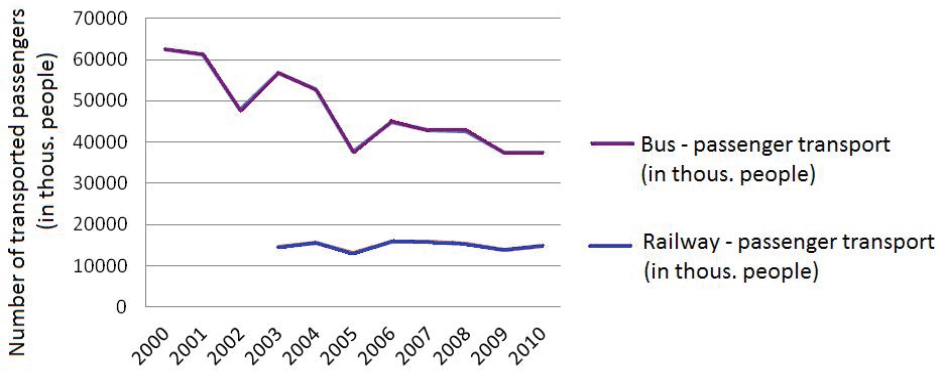

Fig. 7. Number of passengers transported by bus and train in the region between 2000-2010 Rys. 7. Liczba pasażerów przewożonych autobusami i pociągami w regionie w latach 2000-2010

\section{Railways}

Since 1970, OKR has performed regular annual levelling measurements of railway structured (once, twice a year). The results of the measurements are then used to plan repairs of the railway structures. At the same time, levelling points fixed to structures are measured in terms of their altitude (station buildings, signal boxes - see Fig. 4, bridge pillars, etc.)

Main defects include:

- defects in directional and height rail alignment,

- rail, switch and minor rail wear,

- $\quad$ increased sleeper wear (especially wooden sleepers).

\section{Reclamation}

The extraction downturn entailed changes in the sources and objectives of transport including the characteristics of traffic flows of all transport routes and connections. It is therefore necessary to identify the consequences of mining in this area, reclaim the land (see Fig. 6), reconstruct civil structures and ensure safe and reliable transport services.

\section{Discussion}

Transport plays a major role in the development of the Ostrava agglomeration. The development of freight transport is closely related to the development (or decline) of the industry, the importance of passenger transport is then related to the increase (or decrease) in the number of employees working in a specific industry and the average speed increase. Under current conditions, railway and road transport play a major role, air transport is additional and water transport is only mentioned for the future. The railway network establishes a number of important stations and transport hubs including mainly Bohumín and Ostrava. In terms of importance, road transport ranks second although its importance is on the rise. The road network of nationwide and regional importance is mainly related to the connection to neighbouring Poland.

A number of partial modifications to the transport system have been carried out in the line routes to support the needs of involved towns and municipalities. The objective of these lines is to give preference to high capacity railway transport to the detriment of bus transport, which was mainly implemented by removing parallel bus and tram, or trolleybus lines.

The transport flow trend is shown in Tab. 1. It also show an increase in the number of trucks with all negative accompanying impacts on the inhabitants, such as noise nuisance, emissions, traffic safety and generally deteriorating environment caused by traffic. The survey indicates a shift of the transport freight to the road from other means of transport, see Fig. 7. There is also a clear drop in bus transport including public transport.

The effects of mining are a strongly negative factors for using industrial railways for public (suburban) transport. Tram, train, train-tram, bimodal tram, are names given to the transport system and vehicles enabling the transfer from train railways to tram railways, or a railway having mixed features (e.g. train railway in a municipality along the street). Traintrams for Ostrava could take up on the tradition of narrow gauge suburb railways in the area. We can consider mainly the Ostrava - Orlová track.

The idea of renewing light railway transport between Ostrava and through Petřkovice (Ostrava) and Ludgeřovice appeared in the Transport Master Plan of the City of Ostrava in 1997 at the initiative of the General Directorate of Czech Railways. However, the costs of construction are hard to cover as it is estimated at 2 billion CZK.

The introduction of train-trams between Ostrava and Havírov has been a theoretical idea so far. It would expect the use of the existing train railway between these citifies and construction of a new tram railway from the Havírov Hlavní station and Dlouhá třída.

To assess the suitability of the railway sections of the individual industrial railways for public (suburban) transport it is necessary to consider the range of the effects of undermining an its time factor. Inspiration may also be found in similar industrial agglomerations abroad, such as the transport model in Karlsruhe in the Federal Republic of Germany. 


\section{Conclusion}

The development of mining in the past years was subject to a functional transport system, with prevailing requirements for the transportation of large volumes of extracted material, structural elements and people working in this industry. With the extraction downturn, the sources and objectives of transport have changed including the characteristics of transport flows of all traffic roads and connections. Thus, in this area it is necessary to identify the consequences of mining, reclaim the landscape, reconstruct civil structures and ensure safe and reliable transport through trans- port-engineering measures which may ensure the required transport standard and minimise its adverse environmental impacts.

\section{Acknowledgements}

The works were supported from sources for conceptual development of research, development and innovations for 2015 at the VŠB - Technical University of Ostrava which were granted by the Ministry of Education, Youths and Sports of the Czech Republic.

\section{Literatura - References}

1. Q. Jia, N.Al Ansari, S. Knutsson, S. Dust Generation Within the Vicinity of Malmberget Mine, Sweden, In: ADVANCES IN CIVIL ENGINEERING, PTS 1-4 Book Series: Applied Mechanics and Materials, Vol. 90-93, p. 752-759

2. Balcar, Z. and E. Černá. Ročenka dopravy velkých měst, r. 2003 (Transport Yearbook of large cities, 2003), UDI Praha, 2006.

3. Balcar, Z. and E. Černá. Ročenka dopravy velkých měst, r. 2005, (Transport Yearbook of large cities, 2005), UDI Praha, 2006.

4. Balcar, Z.,Černá, E. and M. Šubrt. Ročenka dopravy velkých měst, r. 2010, (Transport Yearbook of large cities, 2010), UDI Praha, 2011.

5. Lahuta, H. a D. Cihlářová. EXPERIENCE WITH MATHEMATICAL MODELING IN PROGRAM PLAXIS: DESIGN AND ASSESSMENT OF RETAINING WALLS. In: Conference proceedings 12th International Multidisciplinary Scientific GeoConference \& EXPO SGEM 2012. Bulgaria: STEF92 Technology Ltd., Sofia, 2012, s. 87-94. ISSN 1314-2704.

6. Řezáč, M., Cihlářová, D., Seidler, T., a P. Šimoník. Options to Mitigate Congestion on Roads In: Conference proceedings International Conference on Civil Engineering, Architecture and Building Materials, CEABM 2013. Jinan, China: May 25-26. 2013, Vols. 361-363 (2013) pp 2049-2052, ISSN 1660-9336. ISBN 978-3-03785-777-9.

7. Řezáč, M., Cihlářová, D. a M. Kludka. Operation of Intelligent Transportation Systems of the City Ostrava in Czech Republic. In: Conference proceedings 13th International Multidisciplinary Scientific GeoConference \& EXPO SGEM 2013. Bulgaria: June 16-22, 2013, Vols. 1 (2013) pp 183-190, ISSN 1314-2704, ISBN 978-954-91818-9-0.

8. Cihlářová, D., Seidler, T. a M. Řezáč. Roads Problems on Undermined Areas in the Moravian-Silesian region. In: Conference proceedings The 3rd International Conference on Civil Engineering and Transportation, ICCET 2013. Kunming, China: December 14-15, 2013. Vols. 505-506, pp. 477-480. ISBN 978-3-03835-006-4.

9. Hudeček L. and D. Cihlářová. The Problems of Railways in the Undermined Areas. In: Conference proceedings 15th International Multidisciplinary Scientific GeoConference SGEM 2015. Bulgaria: June 18-24, 2015, Book1 Vol. 3, 713-718 pp. ISBN 978-619-7105-33-9 / ISSN 1314-2704.

10. Seidler, T., M. Mihola, D. Cihlářová, a M. Krajčovič. Predikce poruch pozemních (Fault prediction roads in undermined areas) komunikací na poddolovaném území. In: Sborník vědeckých prací VŠB-TU Ostrava: řada stavební. 2011, XI(2), 229 - 234. ISSN 1213-1962.

11. Michalowski M., Dudzicz, K., and B.Tora. CO2 emissions with the option of reduce on the example of the EDF Poland S.A. In: Inzynieria Mineralna. Vol.15, is.1, p. 269-274, 2014. ISSN 1640-4920.

12. Hycnar, J.J., Szczygielski, T. And B. Tora. Current state and prospects of increased product-oriented utilization of CCPs. In: Inzynieria Mineralna. Vol.15, is.1, p. 131-142, 2014. ISSN 1640-4920.

13. Hudeček, V., Zapletal, P. and V. Zubíček. The protection against methane leakage from undermined areas. In Inzynieria Mineralna. Vol.16, is.1, p. 115-120, 2015. ISSN 1640-4920.

14. Černota, P., Schenk, J. And J.Mučková. High voltage power transmission line in undermined areas. In: In Inzynieria Mineralna. Vol.14, is.2, p. 1-6, 2013. ISSN 1640-4920. 
15. Černota, P., Staňkova, H., Gašinec, J. and S. Labant, S. New method of swing observation to determine accurate plummet position at the plumb line for both connecting surveys and orientation measurements. In: Acta Montanistica Slovaca. Vol.19, is.4, p. 221-227, 2014. ISSN 1335-1788.

16. Cápayová, S., Zuzulová, A., Bačová, K. Properties of asphalt mixtures with reclaimed material in Slovakia (2015) Green Building, Materials and Civil Engineering - Proceedings of the 4th International Conference on GreenBuilding, Materials and Civil Engineering, GBMCE 2014, pp. 17-20. ISBN: 978-113802669-8

Niezawodność systemu transportu w obszarze dotkniętym podziemna działalnościa górnicza Artykuł dotyczy negatywnego wpływu wydobycia na sieć transportową na obszarze morawsko- śląskim, w szczególności koncentrujac się na problemach odzwierciedlonych $w$ warstwach konstrukcyjnych struktur transportowych (koleje, drogi, obszary magazynowania i przeładunku). Wraz ze spadkiem wydobycia zmienity się sposoby i cele transportu, w tym charakterystyka przeplywów transportowych na wszystkich drogach i połaczeniach komunikacyjnych. Zidentyfikowano różne środki transportu zlokalizowane w regionie morawsko-śląskim. Opisano również nowe istotne kierunki rozwoju transportu z uwzględnieniem wydajności i skuteczności. Podejmowane sa również działania mające na celu minimalizację potrzeb, negatywny wplyw na zdrowie i jakość naszego środowiska przy jednoczesnym zapewnieniu usług transportowych $w$ regionie. Dynamiczny rozwój aglomeracji ostrawskiej jest zatem nierozerwalnie zwiazzany $z$ wydobyciem wegla kamiennego, metalurgia i rozwojem kolei. Lokalizacja firm wydobywczych była ustalana przez położenie złoża, co spowodowało powstanie policentrycznego systemu osadnictwa w aglomeracji. Rozwój kolei weglowych pod koniec XIX wieku związany był z możliwościami wydobywczymi w regionie Karwina. Największy boom przemysłowy i rozwój nastąpił na poczatku XX wieku, kiedy ogromne zmiany nastapity w calym rejonie Ostrawy. Po $1989 \mathrm{r}$. wraz ze zmniejszeniem prac wydobywczych, w OKD zaczęły pojawiać się pierwotne „tereny poprzemysłowe”, będace obiektami przemysłowymi kopalń, a także wtórne "tereny poprzemysłowe”, które były nieużywanymi bocznicami kolejowymi i łączacymi bocznice kolejowe. Wydajny i komfortowy system infrastruktury transportowej wydaje się być kluczowym czynnikiem dla przyszłego rozwoju tego obszaru. Rozwój górnictwa w ostatnich latach byl uwarunkowany przez system transportu, $z$ dominującymi wymaganiami dotyczacymi transportu dużych ilości wydobytego materiału, elementów konstrukcyjnych i osób pracujących w tej branży. Wraz ze spadkiem wydobycia zmienity się źródła $i$ cele transportu, w tym charakterystyka przepływów transportowych na wszystkich drogach i połaczeniach komunikacyjnych. Dlatego w tym obszarze należy zidentyfikować konsekwencje wydobycia, odzyskać krajobraz, zrekonstruować konstrukcje cywilne oraz zapewnić bezpieczny i niezawodny transport za pomoca środków inżynierii transportowej, które moga zapewnić wymagany standard transportu i zminimalizować jego negatywny wplyw na środowisko

Słowa kluczowe: obszar pokopalniany, rewitalizacja terenu, budowle cywilnych, konstrukcje cywilne, tereny poprzemysłowe, budowa linii 